\title{
Verzeichnis der Karten und Pläne
}

1. Karte zur Besitzergreifung der Pampa und des Chaco .. .. . . . . . .. 209

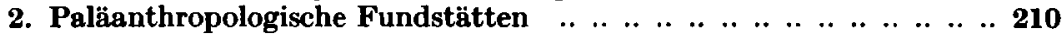

3. Verteilung der Urbevölkerung zur Zeit der Conquista $\quad . . . . . . . . .211$

4. Stammtafel der Argentiner.. .. . . . . . . . . . . . . . . . . . . . . . . . . . . . . . .. 212

5. Territoriale Verteilung der Bevölkerung nach rassischen Gesichts-

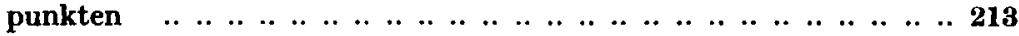

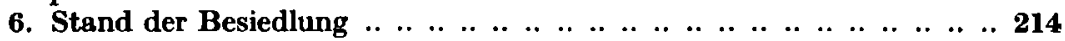

7. Hydrographie der Pampa und der Provinz Entre Ríos $\quad . . \quad$. . . . . .

8. Siedlungen und Eisenbahnen im Zwischenstromlande .. .. ... .. .. .. 216

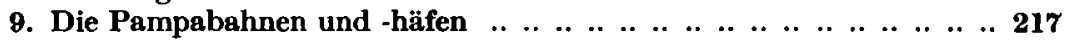

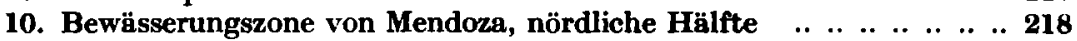

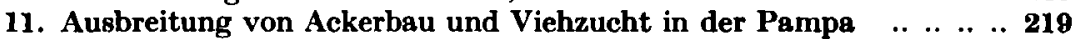

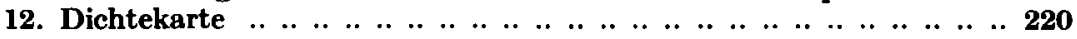

13. Verteilung der Einwanderer 1918-1927 .. .. .. . . . . . ... . . . . . . . . 221

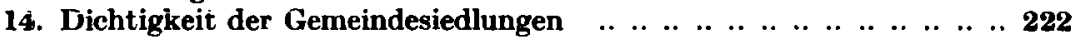

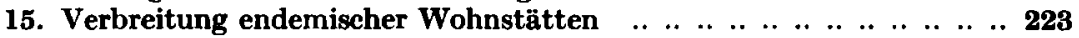

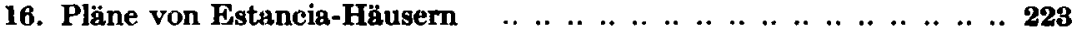

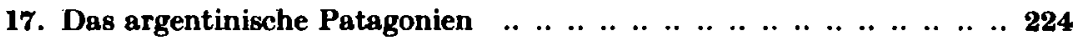

18a. Normalplan einer Stadtsiedelung mit Ejido .. . . . . . . . . . . . . . . . . . 225

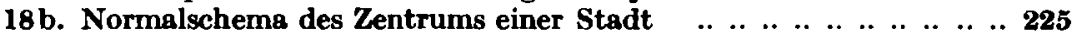

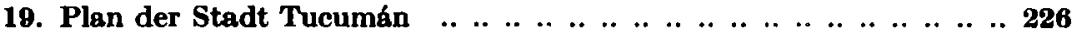

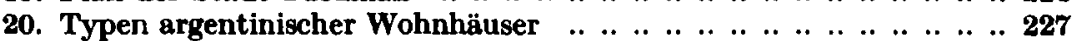

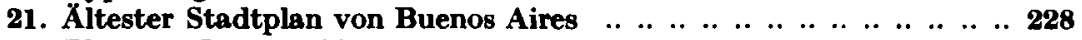

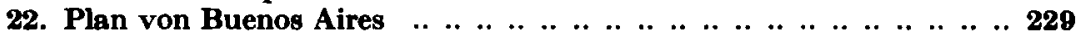

23. Wasserscheide und Grenze zwischen $43^{\circ}$ und $45^{\circ}$ s. B. ... ... ... ... 229

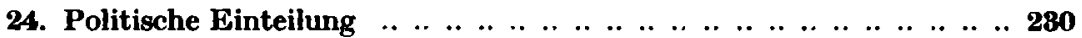

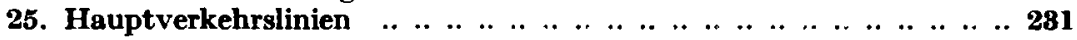
Wirtschaftskarte am Schluß 